\title{
Association between Complement System, Inflammatory Cytokines and Glucose Control in Obese Subjects
}

\author{
Essam H Jiffri ${ }^{1 *}$, Norah S Alhammad ${ }^{2}$, Afnan E Jiffri ${ }^{3}$ and Toleen M Alawadi ${ }^{2}$ \\ ${ }^{1}$ Department of Medical Laboratory Technology, King Abdulaziz University, Saudi Arabia \\ ${ }^{2}$ Department of Dermatology, King Fahad Armed Forces Hospital, Saudi Arabia \\ ${ }^{3}$ Faculty of Medicine, King Abdulaziz University, Jeddah, Saudi Arabia
}

Submission: January 08, 2018; Published: January 24, 2018

*Corresponding author: Essam H Jiffri, Department of Medical Laboratory Technology, Faculty of Applied Medical Sciences, King Abdulaziz University, P.O. Box 80324, Jeddah, 21589, Saudi Arabia, Email: ejiff@hotmail.com

\begin{abstract}
Background: Obesity is frequently characterized by chronic systemic inflammation and insulin resistance (IR). Obesity-associated low grade systemic inflammation is responsible for the complement system activation of which the third component (C3) plays the central role.

Objective: This study aimed to detect the association between complement system, inflammatory cytokines and glucose control in obese subjects.

Methods: Seventy-nine volunteers obese subjects were interviewed, only 68 of them met eligibility criteria, signed the consent form to participate in this study. Their age ranged from 26-43 years and their body mass index (BMI) ranged from 30 to $37 \mathrm{~kg} / \mathrm{m}^{2}$. In the other hand sixty lean subjects (BMI $\leq 25 \mathrm{~kg} / \mathrm{m}^{2}$ ) were participated in the study as a control group, the mean age was $36.18 \pm 5.84$ year and body mass index (BMI) was $\leq 25 \mathrm{~kg} / \mathrm{m}^{2}$. All participants who were assigned into two groups, group (A) consisted of 68 obese subjects and group (B) consisted of 60 lean subjects.
\end{abstract}

Results: The mean values of HBA1c, HOMA-IR, C3, C4, TNF- $\alpha$, Il-6, CRP were significantly higher in the obese group than in the lean control group. In the other hand, the mean value of QUICKI was significantly lower in the obese group than in the lean control group. However, HBA1c and HOMA-IR showed a strong direct relationship with C3, C4, TNF- $\alpha$, Il-6 and CRP, while QUICKI showed a strong inverse relationship with C3, C4, TNF- $\alpha$, Il-6 and CRP in the obese group $(\mathrm{P}<0.05)$.

Conclusion: The present study suggests that in obese subjects there is an association between complement system, inflammatory cytokines and glucose control.

Keywords: Complement system; Cytokines; Obesity; Glucose control

\section{Introduction}

Recently, Obesity is a global medical problem as it affects about $13 \%$ of population worldwide [1]. Obesity is usually associated with impaired insulin sensitivity and insulin resistance [2,3]. Adipose tissue is a storage site and has secretory functions for some secretions of certain biological functions [4]. In addition, adipose tissues has adipocytes and non-adipocytes that include immune cells [5]. Adipose tissue in obese subjects contribute to excessive hepatic production of pro-inflammatory cytokines and serum complement proteins 3 \&4 (C3 \& C4) [6], which are associated with cardiovascular risk factors, insulin resistance, metabolic syndrome and type 2 diabetes mellitus (T2DM) $[7,8]$. However, there was an association between C3 \& C4 with body mass index (BMI) and fat mass [9].

It is well-established that inflammation in obesity is characterized by a low-grade systemic inflammation [10] that leads to an increase in pro-inflammatory proteins such as C-reactive protein (CRP) and interleukin-6 (IL-6) [11] and some components of complement system [12]. The complement system is mainly associated with innate immunity. However, recent studies have shown that this system is involved in 
metabolic events [13]. The majority of complement components are synthesized mainly by hepatocytes, but also can be produced by other cells such as macrophages and adipocytes [14]. Recently, it was demonstrated that serum complement factor 3 (C3) synthesis can be up-regulated by pro-inflammatory cytokines IL- 6 and interleukin- 1 beta (IL-1 $\beta$ ), while serum complement factor 4 (C4) can be influenced by gamma interferon (IFN- $\gamma$ ) $[15,16]$. This study aimed to detect the association between complement system, inflammatory cytokines and glucose control in obese subjects.

\section{Patients and Methods}

\section{Subjects}

Seventy-nine volunteers obese subjects were interviewed, only 68 of them met eligibility criteria, signed the consent form to participate in the study at the Internal Medicine Department at King Abdul Aziz University Hospital. Participants were enrolled between January 2017 and April 2017. Scientific research ethical committee of the Faculty of Applied Medical Sciences, King Abdulaziz University approved this study. Their age ranged from 26-43 years and their body mass index (BMI) ranged from 30 to $37 \mathrm{~kg} / \mathrm{m}^{2}$. While, the exclusion criteria were pregnant women, smoking, patients with body mass index $\geq 40 \mathrm{~kg} / \mathrm{m}^{2}$, subjects taking any medications or herbal supplements, respiratory infection, liver, cardiovascular, renal, endocrine and thyroid diseases. In the other hand sixty lean subjects (BMI $\leq 25 \mathrm{~kg} / \mathrm{m}^{2}$ ) were participated in the study as a control group, the mean age was $36.18 \pm 5.84$ year and body mass index (BMI) was $\leq 25 \mathrm{~kg}$ / $\mathrm{m}^{2}$. All participants who were enrolled into two groups, group (A) consisted of 68 obese subjects and group (B) consisted of 60 lean subjects.

\section{Measurements}

For all subjects, independent assessors who were blinded to group assignment and not involved in the routine treatment of the patients performed clinical evaluations and laboratory analysis. Body mass index (BMI) was calculated on the basis of weight (kilograms) and height (meters), and subjects were classified as normal weight (BMI $18.5-24.9 \mathrm{~kg} / \mathrm{m}^{2}$ ), overweight (BMI $25-29.9 \mathrm{~kg} / \mathrm{m}^{2}$ ), and obese (BMI $\geq 30 \mathrm{~kg} / \mathrm{m}^{2}$ ).

Measurement of inflammatory cytokines: Venous blood samples after a 12-hours fasting were centrifuged at $+4{ }^{\circ} \mathrm{C}$ $(1000=\mathrm{g}$ for $10 \mathrm{~min})$. Interleukin-6 (IL-6) levels were analyzed by "Immulite 2000" immunassay analyzer (Siemens Healthcare Diagnostics, Deerfield, USA). However, tumor necrosis factoralpha (TNF- $\alpha$ ) and C-reactive protein (CRP) levels were measured by ELISA kits (ELX 50) in addition to ELISA microplate reader (ELX 808; BioTek Instruments, USA).

Serum glucose, insulin and insulin resistance tests: Plasma glucose concentration and insulin were determined (Roche Diagnostics GmbH, Mannheim, Germany) using commercially available assay kits. Insulin resistance was assessed by homeostasis model assessment (HOMA-IR). HOMA-
IR $=$ [fasting blood glucose $(\mathrm{mmol} / \mathrm{l})$ fasting insulin $(\mathrm{mIU} /$ $\mathrm{ml}$ )]/22.5 [17]. However, insulin sensitivity was assessed by The quantitative insulin-sensitivity check index (QUICKI) using the formula: QUICKI=1/[log(insulin) + $\log ($ glucose $)][18]$. All serum samples were analyzed in duplicates.

Measurement of complementsystem function: Biomarkers of $\mathrm{C} 3$ and $\mathrm{C} 4$ concentrations were measured from frozen serum samples stored at $-80{ }^{\circ} \mathrm{C}$ by the immunochemiluminometric method (Advia Centaur XP, Siemens, Berlin, Germany).

\section{Statistical Analysis}

SPSS (Chicago, IL, USA) version 21 was used for statistical analysis of data. Quantitative variables were described as mean \pm SD. An independent t-test was used to compare mean values of each parameter among the groups. To observe possible relationships between C3, C4, HBA1c, HOMA-IR, QUICKI, TNF- $\alpha$, Il-6, CRP, Pearson's correlation coefficient ( $r$ ) was used. All assumptions were carefully appreciated in each model we followed. All variables with p- value less than 0.05 were considered as statistical significance.

\section{Results}

Detailed baseline characteristics of the obese group and the lean group presented in Table 1. Comparison between both groups regarding baseline variables showed that there was no statistically significant difference between the both groups as regards age and gender, while the rest of variables the obese group showed significant differences (Table 1).

Table 1: Characteristics of all participants.

\begin{tabular}{|c|c|c|c|}
\hline Age (year) & $\begin{array}{c}\text { Obese Group } \\
\text { (No=68) }\end{array}$ & $\begin{array}{c}\text { Lean Group } \\
\text { (No=60) }\end{array}$ & Significance \\
\hline $\begin{array}{c}\text { Gender (male/ } \\
\text { female) }\end{array}$ & $42 / 26 \pm 7.27$ & $36.18 \pm 5.84$ & $\mathrm{P}>0.05$ \\
\hline BMI (kg/m2) & $35.32 \pm 2.15$ & $22.46 \pm 1.78$ & $\mathrm{P}<0.05$ \\
\hline $\begin{array}{c}\text { Body fat mass (kg) } \\
\text { Fat mass (\%) }\end{array}$ & $39.11 \pm 5.26$ & $25.54 \pm 2.93$ & $\mathrm{P}<0.05$ \\
\hline $\begin{array}{c}\text { Total cholesterol } \\
\text { (mg/dL) }\end{array}$ & $213.27 \pm 18.13$ & $191.17 \pm 15.22$ & $\mathrm{P}<0.05$ \\
\hline $\begin{array}{c}\text { Triglycerides (mg/ } \\
\text { dL) }\end{array}$ & $92.16 \pm 11.54$ & $80.13 \pm 9.85$ & $\mathrm{P}<0.05$ \\
\hline $\begin{array}{c}\text { HDL cholesterol } \\
\text { (mg/dL) }\end{array}$ & $53.19 \pm 6.37$ & $62.41 \pm 8.51$ & $\mathrm{P}<0.05$ \\
\hline $\begin{array}{c}\text { LDL cholesterol } \\
\text { (mg/dL) }\end{array}$ & $126.25 \pm 13.69$ & $108.31 \pm 11.12$ & $\mathrm{P}<0.05$ \\
\hline $\begin{array}{c}\text { Fasting glucose (mg/ } \\
\text { dL) }\end{array}$ & $97.36 \pm 10.43$ & $90.42 \pm 8.75$ & $\mathrm{P}<0.05$ \\
\hline $\begin{array}{c}\text { Insulin (lIU/mL) } \\
\text { (mo. }\end{array}$ & $15.78 \pm 4.28$ & $8.53 \pm 3.16$ & $\mathrm{P}<0.05$ \\
\hline
\end{tabular}

BMI: Body Mass Index; HDL-c: High-density Lipoprotein Cholesterol; LDL-c: Low-Density Lipoprotein Cholesterol; $\left({ }^{*}\right)$ indicates a significant difference between groups, $\mathrm{P}<0.05$. 


\section{Current Research in Diabetes \& Obesity Journal}

Table 2: The mean value and the significance values of different parameters in both groups.

\begin{tabular}{|c|c|c|c|c|}
\hline & Mean +SD & & T-value & Significance \\
\hline & Obese group (No=68) & Lean group (No=60) & & P $<0.05$ \\
\hline C3(mg/dL) & $197.48 \pm 17.35^{*}$ & $124.63 \pm 13.81$ & 8.12 & $P<0.05$ \\
\hline C4(mg/dL) & $39.23 \pm 6.94^{*}$ & $22.57 \pm 3.72$ & 6.45 & $P<0.05$ \\
\hline HBA1c (\%) & $7.24 \pm 1.83^{*}$ & $6.11 \pm 1.54$ & 5.34 & $P<0.05$ \\
\hline QUICKI & $0.15 \pm 0.06^{*}$ & $0.19 \pm 0.07$ & 4.28 & $P<0.05$ \\
\hline HOMA-IR & $3.26 \pm 0.87^{*}$ & $1.94 \pm 0.53$ & 5.14 & $\mathrm{P}<0.05$ \\
\hline TNF- $\alpha(\mathrm{pg} / \mathrm{mL})$ & $8.35 \pm 1.46^{*}$ & $4.17 \pm 1.29$ & 5.45 & $\mathrm{P}<0.05$ \\
\hline IL-6 (pg/mL) & $5.44 \pm 1.27^{*}$ & $3.74 \pm 1.16$ & 4.85 & $\mathrm{P}<0.05$ \\
\hline CRP $(\mathrm{pg} / \mathrm{mL})$ & $4.15 \pm 1.33^{*}$ & $2.38 \pm 0.95$ & 4.69 & \\
\hline
\end{tabular}

C3: Serum Complement Factor 3; C4: Serum Complement Factor 4; HBA1c: Glycosylated Hemoglobin; HOMA-IR: Homeostasis Model Assessment-Insulin Resistance (HOMA-IR) Index; QUICKI: The Quantitative Insulin-Sensitivity Check Index; TNF- $\alpha$ : Tumor Necrosis Factor -Alpha; IL-6: Interleukin-6; CRP: C-reactive Protein; $\left({ }^{*}\right)$ indicates a significant difference between groups, $P<0.05$.

The mean values of HBA1c, HOMA-IR, C3, C4, TNF- $\alpha$, Il-6, CRP were significantly higher in the obese group than in the lean control group. In the other hand, the mean value of QUICKI was significantly lower in the obese group than in the lean control group (Table 2). However, HBA1c and HOMA-IR showed a strong direct relationship with $\mathrm{C} 3, \mathrm{C} 4, \mathrm{TNF}-\alpha, \mathrm{Il}-6$ and CRP, while QUICKI showed a strong inverse relationship with C3, C4, TNF- $\alpha$, Il-6 and CRP in the obese group (Table 3$)(\mathrm{P}<0.05)$.

Table 3: Correlation coefficient ( $r$ ) of HBA1c, HOMA-IR, QUICKI and C3, C4, TNF- $\alpha$, II-6 and CRP in the obese group. Spearman's correlation was used*: $P<0.05^{* *}: P<0.01$.

\begin{tabular}{|c|c|c|c|}
\hline & HOMA-IR & HBA1c (\%) & QUICKI \\
\hline C3(mg/dL) & $0.543^{*}$ & $0.692^{* *}$ & $-0.538^{*}$ \\
\hline $\mathrm{C} 4(\mathrm{mg} / \mathrm{dL})$ & $0.768^{* *}$ & $0.581^{*}$ & $-0.637^{* *}$ \\
\hline $\mathrm{TNF}-\alpha(\mathrm{pg} / \mathrm{mL})$ & $0.519^{*}$ & $0.623^{* *}$ & $-0.615^{* *}$ \\
\hline $\mathrm{IL}-6(\mathrm{pg} / \mathrm{mL})$ & $0.691^{* *}$ & $0.537^{*}$ & $-0.548^{*}$ \\
\hline $\mathrm{CRP}(\mathrm{pg} / \mathrm{mL})$ & $0.628^{* *}$ & $0.542^{*}$ & $-0.685^{* *}$ \\
\hline $\mathrm{TNF}-\alpha(\mathrm{pg} / \mathrm{mL})$ & $0.511^{*}$ & $0.685^{* *}$ & $-0.522^{*}$ \\
\hline
\end{tabular}

\section{Discussion}

Obesity is usually associated with systemic low-grade inflammation which is responsible for complement system and macrophage infiltration $[19,20]$. which are linked with insulin resistance, T2DM and metabolic syndrome [21]. The complement system is mainly associated with innate immunity in addition to be involved in metabolic events [22]. Certainly, complement components $\mathrm{C} 3$ and $\mathrm{C} 4$ are associated with diabetes cardiovascular risk and the metabolic syndrome [23-25].

Concerning inflammatory markers, the results of the present study showed significantly higher values of TNF- $\alpha$, IL- 6 and CRP in obese than the lean control group. Researchers have found that plasma levels of CRP, TNF- $\alpha$, IL- 6 and other inflammatory mediators are elevated in subjects with obesity [26-28]. In correlation analysis, HBA1c and HOMA-IR showed a strong direct relationship with TNF- $\alpha$, Il-6 and CRP, while QUICKI showed a strong inverse relationship with TNF- $\alpha$, Il- 6 and CRP in the obese group. Our findings are similar to many case-controlled researches demonstrated a direct association between HbA1c and inflammatory cytokines [29-36].

Regarding the values of C3 and C4, the present study showed significantly higher values of C3 and C4 in the obese group than the lean group. Our findings agreed with Wlazlo \& colleagues [37] enrolled 532 individuals in their cohort study and reported that there was an association between the degree of body fat and the C3 level [37]. However, several studies reported that C3 and C4 correlated with CRP and other inflammatory markers [38,39]. However, in correlation analysis, HBA1c and HOMA-IR showed a strong direct relationship with C3 and C4, while QUICKI showed a strong inverse relationship with C3 and C4 in the obese group. Our findings agreed with Phillips et al. [40] reported that among 1754 with metabolic syndrome, they found an association between $\mathrm{C} 3$ and insulin resistance, abdominal obesity, low HDL and smoking [40]. Similarly, Koistinen et al. [41] reported that C3 level was associated with 


\section{Current Research in Diabetes \& Obesity Journal}

insulin resistance in in obese nondiabetic subjects and type 2 diabetics [41]. In addition, Onat \& colleagues [42] conducted a cohort study on 1220 adult subjects of general population and they reported that C3 level was associated significantly with waist circumference, triglycerides, CRP, smoking and insulin resistance [42]. Moreover, Wlazlo et al. [43] conducted a 7-year prospective analysis on type 2 diabetes mellitus and found an independent association between $\mathrm{C} 3$ level and insulin resistance [43]. In the other hand, Bratti \& colleagues [44] reported that C3 and C4 were significantly higher with positive correlation with HOMA-IR in morbidly obese patients than lean subjects, while following bariatric surgery there was reduction in triacylglycerol and increase in HDL and insulin sensitivity 6months following surgery [44].

\section{Conclusion}

The present study suggests that in obese subjects there is an association between complement system, inflammatory cytokines and glucose control.

\section{Acknowledgment}

The author thanks Prof. Mohammed Tayeb for his skillful assistance in selection of participants, laboratory analysis and during clamp procedures of this study. In addition, author is grateful for the cooperation and support of all patients who participated in this study.

\section{References}

1. http://www.who.int/mediacentre/factsheets/fs311/en/

2. van Greevenbroek, MM Schalkwijk, CG Stehouwer CD (2013) Obesityassociatedlow-grade inflammation in type 2 diabetes mellitus: causes and consequences. Neth J Med 71(4): 174-187.

3. Kaur J (2014) A comprehensive review on metabolic syndrome. Cardiol Res Pract 2014: 943162.

4. Ouchi N, Parker JL, Lugus JJ, Walsh K (2011) Adipokines in inflammation and metabolic disease. Nat Rev Immunol 11(2): 85-97.

5. Lee BC, Lee J (2014) Cellular and molecular players in adipose tissue inflammation in the development of obesity-induced insulin resistance. Biochim Biophys Acta 1842(3): 446-462.

6. Nestvold TK, Nielsen EW, Ludviksen JK, Fure H, Landsem A, et al. (2015) Lifestyle changes followed by bariatric surgery lower inflammatory markers and the cardiovascular risk factors C3 and C4, Metab Syndr Relat Disord 13(1): 29-35.

7. Hertle E, van Greevenbroek MM, Stehouwer CD (2012) Complement C3: an emerging risk factor in cardiometabolic disease. Diabetologia 55(4): 881-884

8. Onat A, Can G, Rezvani R, Cianflone K (2011) Complement C3 and cleavage products in cardiometabolic risk. Clin Chim Acta 412(13-14): 1711-1179.

9. Engström G, Hedblad B, Eriksson KF, Janzon L, Lindgärde F (2005) Complement C3 is a risk factor for the development of diabetes: a population-based cohort study. Diabetes 54(2): 570-575.

10. Barbu A, Hamad OA, Lind L, Ekdahl KN, Nilsson B (2015) The role of complement factor C3 in lipid metabolism, Mol. Immunol. 67(1): 101107.
11. Nestvold TK, Nielsen EW, Ludviksen JK, Fure H, Landsem A, et al. (2015) Lifestyle changes followed by bariatric surgery lower inflammatory markers and the cardiovascular risk factors C3 and C4, Metab Syndr Relat Disord 13(1): 29-35.

12. Hertle E, van Greevenbroek MM, Stehouwer CD (2012) Complement C3: an emerging risk factor in cardiometabolic disease. Diabetologia 55(4): 881-884.

13. Nilsson B, Hamad OA, Ahlström H, Kullberg J, Johansson L, et al. (2014) C3 and C4 are strongly related to adipose tissue variables and cardiovascular risk factors. Eur J Clin Investig 44(6): 587-596.

14. Wolbink GJ, Brouwer MC, Buysmann S, Ten Berge IJ, Hack CE (1996) RP mediated activation of complement in vivo: assessment by measuring circulating complement C-reactive complexes. J Immunol 157(1): 473479 .

15. Makki K, Froguel P, Wolowczuk I (2013) Adipose tissue in obesityrelated inflam-mation and insulin resistance: cells, cytokines, and chemokines. ISRN Inflamm 2013: 139239.

16. Błogowski W, Budkowska M, Sałata D, Serwin K, Dołęgowska B, et al. (2013) Clinical analysis of selected complement-derived molecules in human adipose tissue. J Transl Med 11: 11.

17. Wärnberg J, Nova E, Moreno LA, Romeo J, Mesana MI, et al. (2006) Inflammatory proteins are related tototal and abdominal adiposity in a healthy adolescent population: the AVENA Study. Am J Clin Nutr 84(3): 505-512.

18. Hillian AD1, McMullen MR, Sebastian BM, Roychowdhury S, Kashyap SR, et al. (2013) Mice lacking C1q areprotected from high fat dietinduced hepatic insulin resistance and impairedglucose homeostasis. J Biol Chem 288(31): 22565-22575.

19. Matthews DR, Hosker JP, Rudenski AS, Naylor BA, Treacher DF, et al. (1985) Homeostasis model assessment: insulin resistance and beta cell function from plasma FBS and insulin concentrations in man. Diabetologia 28(7): 412-419.

20. Katz A, Nambi SS, Mather K, Baron DA, Follman DA, et al. (2000) Quantitative insulin sensitivity check index: a simple, accurate method for assessing insulin sensitivity in humans. J Clin Endocrinol Metab 85(7): 2402-2410.

21. Albakri A, Al Domi H, Majdalani K, Nawaiseh H (2014) Adipose tissue remodeling and its effect on insulin sensitivity in obese individuals: a critical review. Jordan J Agric Sci 10: 215-224.

22. Wlazlo N, van Greevenbroek MM, Ferreira I, Jansen EJ, Feskens EJ, et al. (2012) Low-grade inflammation and insulin resistance independently explain substantial parts of the association between body fat and serum C3: the CODAM study. Metabolism 61(12): 1787-1796.

23. Weyer C, Tataranni PA, Pratley RE (2000) Insulin action and insulinemia are closely related to the fasting complement $\mathrm{C} 3$, but not acylation stimulating protein concentration. Diabetes Care 23(6): 779-785.

24. Engstrom G, Hedblad B, Eriksson KF, Janzon L, Lindgarde F (2005) Complement C3 is a risk factor for the development of diabetes: a population-based cohort study. Diabetes 54(2): 570-575.

25. Onat A, Hergenc G, Can G, Kaya Z, Yuksel H (2010) Serum complement C3: a determinant of cardiometabolic risk, additive to the metabolic syndrome, in middle-aged population. Metabolism 59(5): 628-634.

26. Palikhe A, Sinisalo J, Seppanen M, Haario H, Meri S (2007) Serum complement C3/C4 ratio, a novel marker for recurrent cardiovascular events. Am J Cardiol 99(7): 890-895.

27. Burke AP, Tracy RP, Kolodgie F, Malcom GT, Zieske A, et al. (2002) Elevated C-reactive protein values and atherosclerosis in sudden coronary death: Association with different pathologies. Circulation 105(17): 2019-2023. 
28. Dandona P, Weinstock R, Thusu K, Abdel Rahman E, Aljada A, et al. (1998) Tumor necrosis factor-alpha in sera of obese patients: fall with weight loss. J Clin En-docrinol Metab 83(8): 2907-2910.

29. Wakabayashi I (1998) Age-related change in relationship be-tween body-mass index, serum sialic acid, and athero-genic risk factors. J Atheroscler Thromb 5(2): 60-65.

30. King D, Mainous A, Buchanan T, Pearson W (2003) C-Reactive protein and glycemic control in adults with diabetes. Diabetes Care 26(5): 1535-1539.

31. Lecheitner M, Herold M, Dzien Bischinger, Hoppichler F, Dzien A (2002) Tumor necrosis factor-alpha plasma levels in elderly patients with type 2 diabetes mellitus e observations over 2 years. Diabet Med 19(11): 949-953.

32. Wu T, Dorn JP, Donahue RP, Sempos CT, Trevisan M (2002) Associations of serum C-reactive protein with fasting insulin, glucose, and glycosylatedd hemoglobin. Am J Epidemiol 155(1): 65-71.

33. Salmenniemi U, Vauhkonen I, Kainulainen S, Punnonen K, Vanninen E, et al. (2004) Multiple abnormalities in glucose and energy metabolism and coordinated changes in levels of adiponectin, cytokines, and adhesion molecules in subjects with metabolic syndrome. Circulation 110(25): 3842-3848.

34. Ryan AS, Nicklas BJ (2004) Reductions in plasma cytokine levels with weight loss improve insulin sensitivity in overweight and obese postmenopausal woman. Diabetes Care 27(7): 1699-1705.

35. Moran MR, Romero FG (1999) Increased levels of C-reactive protein in noncontrolled type II diabetic subjects. J Diab Comp 13(4): 211-215.

36. Mishima Y, Kuyama A, Tada A, Takahashi K, Ishioka T, et al. (2001) Relationship between serum tumor necrosis factor-a and insulin resistance in obese men with Type 2 diabetes mellitus. Diabetes Research and Clinical Practice 52 (2): 119-123.
37. Wlazlo N, van Greevenbroek MM, Ferreira I, Jansen EJ, Feskens EJ, et al. (2012) Low-grade inflammation and insulin resistance independently explain substantial parts of the association between body fat and serum C3: The CODAM study. Metabolism 61(12): 1787-1796.

38. Mavridis G, Souliou E, Diza E, Symeonidis G, Pastore F, et al. (2008) Inflammatory cytokines in insulin-treated patients with type 2 diabetes. Nutr Metab Cardiovasc Dis 18(7): 471-476.

39. Luc G, Empana JP, Morange P, Juhan Vague I, Arveiler D, et al. (2010) Adipocy-tokines and the risk of coronary heart disease in healthy middle aged men: the PRIME Study. Int J Obes 34(1): 118-126.

40. Phillips CM, Kesse Guyot E, Ahluwalia N, McManus R, Hercberg S, et al. (2012) Dietary fat, abdominal obesity and smoking modulate the relationship between plasma complement component 3 concentrations and metabolic syndrome risk. Atherosclerosis 220(2): 513-519.

41. Koistinen H, Koivisto V, Ebeling P (2000) Serum complement protein C3 concentration is elevated in insulin resistance in obese men. European Journal of Internal Medicine 11(1): 21-26.

42. Hertle E, van Greevenbroek MM, Arts IC, van der Kallen CJ, Feskens EJ, et al. (2014) Complement activation products C5a andsC5b-9 are associated with low-grade inflammation and endothelial dysfunc-tion, but not with atherosclerosis in a cross-sectional analysis: The CODAM study. Int J Cardiol 174(2): 400-403.

43. Wlazlo N, van Greevenbroek MM, Ferreira I, Feskens EJ, van der Kallen CJ, et al. (2014) Complement factor 3 is associated with insulin resistance and with incident type 2 diabetes mellitus over a 7 -year follow-up period: the CODAM study. Diabetes Care 37(7): 1900-1909.

44. Bratti LO, do Carmo ÍA, Vilela TF, Wopereis S, de Moraes AC, et al. (2017) Complement component 3 (C3) as a biomarker for insulin resistance after bariatric surgery. Clin Biochem 50(9): 529-532.

\begin{tabular}{|l|}
\hline \multicolumn{1}{|c|}{ Your next submission with Juniper Publishers } \\
will reach you the below assets \\
- Quality Editorial service \\
- Swift Peer Review \\
- Reprints availability \\
- E-prints Service \\
- Manuscript Podcast for convenient understanding \\
- Global attainment for your research \\
- Manuscript accessibility in different formats \\
( Pdf, E-pub, Full Text, Audio) \\
- Unceasing customer service \\
Track the below URL for one-step submission \\
https://juniperpublishers.com/online-submission.php \\
\hline
\end{tabular}

